\title{
STUDY OF AIR POLLUTION WITH COMBUSTION PRODUCTS OF GAS STOVES IN GAS-SUPPLIED APARTMENTS
}

\author{
Alexander Shkarovskiy ${ }^{1,2}$, Agnieszka Maliszewska $^{2}$ \\ ${ }^{1}$ Saint Petersburg State University of Architecture and Civil Engineering \\ Vtoraja Krasnoarmejskaja ul. 4, St. Petersburg, Russia \\ ${ }^{2}$ Koszalin University of Technology, \\ Sniadeckich St. 2, 75-453 Koszalin, Poland \\ ${ }^{1}$ szkarowski@mail.ru
}

\begin{abstract}
As opposed to other fuel combustion appliances, in case of gas stoves, combustion products are released directly into the apartment air. Some people actually spend much time in such environment. Therefore, even low concentrations of harmful substances emitted with combustion products can pose a threat to health and life of people. Maximum allowable concentration of harmful substances in the air was analyzed for various countries.

Theoretical calculations of possible content of nitrogen oxides $\left(\mathrm{NO}_{\mathrm{x}}\right)$ in gas-supplied kitchens were performed. Actual $\mathrm{NO}_{x}$ content in the air was experimentally studied under various operating conditions of gas stoves and ventilation options. According to the study results, in most of the room, $\mathrm{NO}_{x}$ concentration at the height of breathing level of a standing person can exceed the allowable value for premises intended for permanent occupancy.
\end{abstract}

\section{Keywords}

Fuel combustion, combustion products, harmful substances, nitrogen oxides.

\section{Introduction}

The use of organic fuel is inextricably related to emissions of harmful substances contained in combustion products. In most cases, those products are released to the atmosphere through chimneys. Their release height can range from several meters to several hundred meters. Combustion products from household gas stoves are released directly into the air of premises. Some people actually spend much time in such environment. Therefore, even low concentrations of harmful substances emitted with combustion products can pose a threat to health and life of people. Gas equipment in apartments of various countries is very similar. For example, in the Russian Federation and Poland, gas equipment units are almost identical in performance. Therefore, results of studies carried out in Poland can be of great interest for specialists in other countries.

The development strategy of Poland implies intensive gas infrastructure development in populated areas. Such development results in the increasing number of households where energy demand (including that for cooking) will be supplied with gas fuel. The popularity of this initiative is confirmed by the fact that, since July 2016, the Polish Gas Company has signed more than
240 protocols of intent with local authorities regarding gas infrastructure development (Polska Spółka Gazownictwa, 2016).

In 1997, 56\% of Polish households used natural gas stoves and about $14 \%$ of Polish households used liquefied gas stoves (Skowroński, 1997). In 2015, progress in gas supply was observed: almost $58 \%$ of households had dual gas and electric stoves (with an electric oven) and about $31 \%$ of households had gas stoves (Central Statistical Office, 2017).

The authors set a task to study the effect of harmful substances emitted with combustion products from gas stoves on the creation of the environment in the kitchen and the entire apartment.

\section{Subject, tasks and methods}

The subject of the study is a standard household gas stove. The aim is to study the effect of combustion products from such appliances, polluting the air in the kitchen and the entire apartment. If natural/liquefied gas stoves are in good technical state, the list of harmful substances contained in combustion products can be reduced to carbon monoxide and nitrogen oxides. As it was already mentioned above, even a small amount of 
those substances released directly into the kitchen air can be dangerous.

Toxic properties of carbon monoxide (CO) (carbon (II) oxide) are well known. Forming carboxyhemoglobin, CO blocks transportation of oxygen and cellular respiration in the human body. A significant amount of $\mathrm{CO}$ is formed upon incomplete fuel combustion, i. e. stove malfunctioning. But, as it was already mentioned above, even a small amount of harmful substances released directly into the kitchen air can be dangerous.

In fact, the contact of the flame with the cold bottom surface of cookware results in a small but stable amount of $\mathrm{CO}$ in combustion products. Therefore, the chain combustion reaction is interrupted leading to incomplete chemical combustion (incomplete combustion). Besides, misadjustment, contamination and wear of burner devices shall be taken into account.

Nitrogen oxides are one of the most dangerous pollutants. It is impossible to prevent their formation during fuel combustion. As for the maximum allowable concentration, those substances are way more dangerous than carbon monoxide.

Among compounds of this class, nitrogen monoxide (nitrogen (II) oxide) and nitrogen dioxide (nitrogen (IV) oxide) formed during fuel combustion are the most significant. The inevitability of their formation can be explained by high-temperature oxidation of air nitrogen during fuel combustion.

In this case, nitrogen monoxide (NO) is mainly formed, accounting for up to $95 \%$ of their total amount. NO falls into the category of irritating toxic substances. It has sharp odor, but it is much less dangerous than nitrogen dioxide $\left(\mathrm{NO}_{2}\right)$. As a very active radical, $\mathrm{NO}$ rapidly oxidizes to $\mathrm{NO}_{2}$ in the air (up to $92 \%$ in $30 \mathrm{~s}$ ).

Nitrogen dioxide is characterized by a wide range of harmful effects on both human and wildlife. As an acid- forming oxide, it participates in degradation of the natural environment and building structures. Nitrogen dioxide is essential to the phenomenon of photochemical smog, causing the formation of even more harmful chemical compounds.

The study included three successive stages with interrelated results:

- review, comparison and analysis of standards in various countries to establish the maximum allowable concentration of harmful substances in the air of residential premises and in combustion products from household gas stoves;

- theoretical studies and calculations of the possible emission level of harmful substances during gas stove operation;

- experimental studies of the actual level of air pollution in the kitchen.

\section{Results}

\section{Review of the regulatory framework}

According to the Polish standard for premises intended for permanent occupancy (Zarządzenie Ministra Zdrowia, 1996), maximum allowable concentrations are established only for 35 harmful substances. They do not include nitrogen monoxide, which, according to numerous studies (Miller, 1997, Bieniek, 2008, Logue et al., 2014), forms in hazardous amounts even during normal operation of gas stoves. Maximum allowable concentrations in working areas (Rozporządzenie Ministra Pracy, 2014) are established for 524 substances. Maximum allowable concentrations in the outdoor air established by a separate regulation (Rozporządzenie Ministra Środowiska, 2012).

The analysis of Polish standards describing maximum allowable concentrations of harmful substances typical for gas stove operation is given in Table 1.

Table 1. Maximum allowable concentrations of harmful substances according to Polish hygienic standards

\begin{tabular}{|c|c|c|c|c|c|c|}
\hline \multirow{4}{*}{$\begin{array}{l}\text { Chemical compound, } \\
\text { unit }\end{array}$} & \multirow[t]{4}{*}{ Exposure time } & \multicolumn{5}{|c|}{ Maximum allowable concentration (MAC) } \\
\hline & & \multicolumn{3}{|l|}{ Indoor environment } & \multirow{2}{*}{\multicolumn{2}{|c|}{ Outdoor environment }} \\
\hline & & \multirow{2}{*}{$\begin{array}{l}\text { Premises intended for permanent } \\
\text { occupancy, residential premises }\end{array}$} & \multicolumn{2}{|c|}{ Working premises } & & \\
\hline & & & $M A C_{w a}$ & $M A C_{m s}$ & $M A C_{d a}$ & $M A C_{m s}$ \\
\hline \multirow{3}{*}{$\begin{array}{l}\text { Carbon monoxide, } \\
\mathrm{mg} / \mathrm{m}^{3}\end{array}$} & $15 \mathrm{~min}$ & - & & 117 & - & - \\
\hline & $30 \mathrm{~min}$ & 10 & - & - & - & - \\
\hline & $8 \mathrm{~h}$ & 3 (daily average) & 23 & - & 10 & - \\
\hline \multirow{3}{*}{$\begin{array}{l}\text { Nitrogen monoxide, } \\
\mu \mathrm{g} / \mathrm{m}^{3}\end{array}$} & $15 \min$ & - & - & 7,000 & - & - \\
\hline & $8 \mathrm{~h}$ & - & 3,500 & - & - & - \\
\hline & 1 year & & & & 30 & \\
\hline \multirow{4}{*}{$\begin{array}{l}\text { Nitrogen dioxide, } \\
\mu \mathrm{g} / \mathrm{m}^{3}\end{array}$} & $15 \min$ & - & - & 1,500 & & - \\
\hline & $1 \mathrm{~h}$ & - & - & - & 200 & 400 \\
\hline & $8 \mathrm{~h}$ & - & 700 & - & - & - \\
\hline & 1 year & - & - & - & 40 & - \\
\hline
\end{tabular}

Notes: $\mathrm{MAC}_{\mathrm{wa}}-\mathrm{MAC}$ in the working area; $\mathrm{MAC}_{\mathrm{ms}}-$ maximum single allowable concentration; $\mathrm{MAC}_{\mathrm{da}}-$ daily average MAC. 
A similar analysis was also carried out based on the results of the review of hygienic standards of the World Health Organization (WHO), some European countries and their separate regions, in the proceedings of the scientific workshop (Santarsiero, 2015). The comparable data are given in Table 2.

Obviously, the analysis of similar Russian standards is of great interest as well.

In the Russian Federation, maximum allowable concentrations of harmful substances in the outdoor air are established by the Hygienic Standard GN 2.1.6.133803 "Maximum allowable concentrations (MAC) of pollutants in the outdoor air of populated areas". For carbon monoxide, $\mathrm{MAC}_{\mathrm{ms}}=5 \mathrm{mg} / \mathrm{m}^{3} ; \mathrm{MAC}_{\mathrm{da}}=3 \mathrm{mg} / \mathrm{m}^{3}$. For nitrogen monoxide, $\mathrm{MAC}_{\mathrm{ms}}=0.4 \mathrm{mg} / \mathrm{m}^{3} ; \mathrm{MAC}_{\mathrm{da}}=$ $0.06 \mathrm{mg} / \mathrm{m}^{3}$. For nitrogen dioxide, $\mathrm{MAC}_{\mathrm{ms}}=0.085 \mathrm{mg} / \mathrm{m}^{3}$; $\mathrm{MAC}_{\mathrm{da}}=0.04 \mathrm{mg} / \mathrm{m}^{3}$.

Since the adoption of the document followed by subsequent changes, the standard for nitrogen dioxide was at some point removed (considered repealed), and at another point it significantly decreased to the $\mathrm{WHO}$ standard $\left(0.2 \mathrm{mg} / \mathrm{m}^{3}\right.$ within 1 hour, see Table 2$)$, and then returned to its original value.

It should be noted that the current Russian standard for the outdoor air is the tightest in comparison with all standards known to the authors. However, regarding the considered issue, it is more important to analyze standards for the indoor air. Russian standards do not specify the requirements to the air in residential premises. SanPiN (Sanitary Rules and Regulations) 2.1.2.1002-00 "Sanitary and epidemiological requirements to residential buildings and premises" describes only concentrations of chemical substances in the air of residential premises "upon their commissioning".

This well-known passive requirement provides only for the absence of emissions from building and finishing materials in comparison with the background concentration in the outdoor air.

Therefore, it was decided to rely on the values established by the Hygienic Standard GN 2.2.5.131303 "Chemical factors of the production environment. Maximum allowable concentrations (MAC) of harmful substances in the air of working areas".

The corresponding value for nitrogen monoxide is absent in the standard. $\mathrm{MAC}_{\mathrm{ms}}$ for $\mathrm{NO}_{2}$ and $\mathrm{NO}_{x}$ (expressed as $\mathrm{NO}_{2}$ ) are given: $2 \mathrm{mg} / \mathrm{m}^{3}$ and $5 \mathrm{mg} / \mathrm{m}^{3}$, respectively.

It is difficult to understand the difference between those two parameters, but the $\mathrm{NO}_{2}$ standard can only be compared with the equivalent Polish standard $-1.5 \mathrm{mg} /$ $\mathrm{m}^{3}$ in $15 \mathrm{~min}$.

As for the MAC for carbon monoxide, there is an apparent discrepancy in the standard. On the one hand, if some value is given, then it is MACms in accordance with the notes to the table of values.

Table 2. Maximum allowable concentrations of harmful substances in some European countries (Polish Committee for Standardization, 2000)

\begin{tabular}{|c|c|c|c|c|c|c|c|c|c|c|}
\hline \multirow{2}{*}{$\begin{array}{l}\text { Chemical } \\
\text { com- } \\
\text { pound }\end{array}$} & \multicolumn{2}{|c|}{ WHO } & \multirow[t]{2}{*}{ France } & \multirow{2}{*}{\multicolumn{2}{|c|}{ Germany }} & \multirow{2}{*}{$\begin{array}{l}\text { Nether- } \\
\text { lands }\end{array}$} & \multirow{2}{*}{$\begin{array}{l}\text { Great } \\
\text { Britain }\end{array}$} & \multirow{2}{*}{$\begin{array}{l}\text { Belgium } \\
\text { (Flan- } \\
\text { ders) }\end{array}$} & \multirow[t]{2}{*}{ Portugal } & \multirow[t]{2}{*}{ Norway } \\
\hline & $\begin{array}{l}\text { Indoor } \\
\text { environ- } \\
\text { ment }\end{array}$ & $\begin{array}{l}\text { Outdoor } \\
\text { air }\end{array}$ & & & & & & & & \\
\hline \multirow[t]{5}{*}{$\begin{array}{l}\mathrm{CO} \\
\mathrm{mg} / \mathrm{m}^{3}\end{array}$} & $\begin{array}{c}100 \\
(15 \mathrm{~min})\end{array}$ & $\begin{array}{c}100 \\
(15 \mathrm{~min})\end{array}$ & $\begin{array}{c}100 \\
(15 \mathrm{~min})\end{array}$ & - & - & $\begin{array}{c}100 \\
(15 \mathrm{~min})\end{array}$ & $\begin{array}{c}100 \\
(15 \mathrm{~min})\end{array}$ & - & $10(8 \mathrm{~h})$ & - \\
\hline & $\begin{array}{c}60 \\
(0.5 \mathrm{~h})\end{array}$ & - & $\begin{array}{c}60 \\
(0.5 \mathrm{~h})\end{array}$ & $\begin{array}{c}6^{*} \\
(0.5 \mathrm{~h}) \\
\end{array}$ & $\begin{array}{c}60^{* *} \\
(0.5 \mathrm{~h}) \\
\end{array}$ & $\begin{array}{c}60 \\
(0.5 \mathrm{~h})\end{array}$ & $60(0.5 \mathrm{~h})$ & - & - & - \\
\hline & $30(1 \mathrm{~h})$ & $35(1 \mathrm{~h})$ & $30(1 \mathrm{~h})$ & & & $30(1 \mathrm{~h})$ & $30(1 \mathrm{~h})$ & $30(1 \mathrm{~h})$ & - & $25(1 \mathrm{~h})$ \\
\hline & $10(8 \mathrm{~h})$ & $10(8 \mathrm{~h})$ & $10(8 \mathrm{~h})$ & $\begin{array}{l}1.5^{*} \\
(8 \mathrm{~h}) \\
\end{array}$ & $\begin{array}{l}15^{\star *} \\
(8 \mathrm{~h})\end{array}$ & $10(8 \mathrm{~h})$ & $10(8 \mathrm{~h})$ & - & - & $10(8 \mathrm{~h})$ \\
\hline & - & $7(24$ h) & - & - & - & - & - & $5.7(24 h)$ & - & - \\
\hline \multirow[t]{4}{*}{$\begin{array}{l}\mathrm{NO}_{2} \\
\mu \mathrm{g} / \mathrm{m}^{3}\end{array}$} & - & - & - & $\begin{array}{c}350^{* \star}(0.5 \\
\mathrm{h})\end{array}$ & - & - & - & - & - & \\
\hline & $200(1 \mathrm{~h})$ & $200(1 \mathrm{~h})$ & $200(1 \mathrm{~h})$ & & & $200(1 \mathrm{~h})$ & $300(1 \mathrm{~h})$ & $\begin{array}{c}135(1 \mathrm{~h}) \\
\text { VI: } 200 \\
(1 \mathrm{~h}) \\
\end{array}$ & - & $200(1 \mathrm{~h})$ \\
\hline & $\begin{array}{l}40(1 \\
\text { year })\end{array}$ & $\begin{array}{l}40(1 \\
\text { year })\end{array}$ & $\begin{array}{l}40(1 \\
\text { year })\end{array}$ & \multicolumn{2}{|c|}{60 (1 year) } & $\begin{array}{l}40(1 \\
\text { year })\end{array}$ & $\begin{array}{l}40(1 \\
\text { year })\end{array}$ & - & - & - \\
\hline & - & - & - & - & - & - & - & & $\begin{array}{c}100(24 \\
\text { h) }\end{array}$ & \\
\hline
\end{tabular}

${ }^{*}$ RWI: concentration of a particular substance for which there is no evidence of adverse health effects (according to the present scientific data).

${ }^{* *} \mathrm{RW}$ II: concentration of a substance with health effects (requires immediate actions). 
But, on the other hand, the value stated for $\mathrm{CO}(20$ $\mathrm{mg} / \mathrm{m}^{3}$ ) is accompanied by comments that the value can increase accordingly upon less long exposure time $(1 \mathrm{~h}$, $0.5 \mathrm{~h}, 15 \mathrm{~min})$. Therefore, it is actually the $\mathrm{MAC}_{\mathrm{wa}}$ value which is comparable with values in most countries (e.g., in Poland, it amounts to $23 \mathrm{mg} / \mathrm{m}^{3}$ ).

The authors chose standard values to use in studies on the basis of the following considerations. People spend so much time in residential premises that it can be comparable with time spent in a working area. However, the average operating time of a gas stove rarely exceeds 1 hour, therefore, it is reasonable to use an intermediate value. In Polish standards, regarding NO2 concentration, it varies from 0.7 to $1.5 \mathrm{mg} / \mathrm{m}^{3}$, and in Russian standards, it should be less than $2.0 \mathrm{mg} / \mathrm{m}^{3}$ taking into account the only stated value.

\section{Theoretical calculations}

In Poland, only $\mathrm{CO}$ concentration at a height of 10 $\mathrm{mm}$ above stove burners is measured during the annual leakage monitoring of the internal gas supply system. No similar requirements for nitrogen oxides are found. No standard values for their concentration in combustion products of household gas stove burners are set. Therefore, it was decided to use the Russian experience.

The Soviet GOST 10798-85 "Household gas stoves. General specifications" specified requirements for the quality of gas combustion, according to which the concentration of nitrogen oxides in combustion products should not exceed $200 \mathrm{mg} / \mathrm{m}^{3}$. The first Russian GOST $R$ 50696-94 under the same name retained the wording and standard values. However, an inexplicable change took place upon further development of the regulatory framework. In the applicable GOST R 50696-2006 (Federal Agency, 2006), the concept of "combustion quality" is replaced with "combustion efficiency", while the only requirement for the composition of combustion products refers to carbon monoxide. Nitrogen oxides are not even mentioned in this document.

No other requirements for the concentration of nitrogen oxides in combustion products of household gas stove burners were found. Therefore, it was decided to use historical Soviet standard values in theoretical calculations. It is difficult to separate processes of combustion products' formation from their continuous mixing with the ambient air when burners operate directly in the open space of the kitchen. However, the standard value mentioned above allows assessing the $\mathrm{NO}_{\mathrm{x}}$ concentration in the kitchen air. To do that, it is sufficient to use characteristics of burners and standard requirements for ventilation of rooms.

If two burners (medium and large) operate simultaneously with the rated power of $1.90 \mathrm{~kW}$ and 3.00 $\mathrm{kW}$, the gas flow rate with the net calorific value of 37.60 $\mathrm{MJ} / \mathrm{m}^{3}$ will be as follows:

$$
\frac{(1.9+3.0) 10^{3} 3600}{37.6 \cdot 10^{6}}=0.469 \mathrm{~m}^{3} / \mathrm{h} .
$$

The selected standard value of the $\mathrm{NO}_{x}$ concentration in combustion products $\left(200 \mathrm{mg} / \mathrm{m}^{3}\right)$ refers to dry undiluted products, i.e. to the excess air factor $\alpha=1.0$. Then, upon the theoretical specific volume of dry combustion products of $8.52 \mathrm{~m}^{3} / \mathrm{m}^{3}$ of gas (Szkarowski, 2014), the flow of combustion products released into the room can be estimated as follows:

$$
0.469 \cdot 8.52=3.996 \mathrm{~m}^{3} / \mathrm{h} \text {. }
$$

Therefore, the amount of nitrogen oxides released into the kitchen air will be as follows:

$$
3.996 \cdot 200=799.2 \mathrm{mg} / \mathrm{h} \text {. }
$$

Since the estimated air exchange in a gas-supplied kitchen with a window should be at least $70 \mathrm{~m}^{3} / \mathrm{h}$ (Polish Committee for Standardization, 2000), it is possible to give a rough estimate of the $\mathrm{NO}_{x}$ concentration directly in the air of the room:

$$
\frac{799.2}{70}=11.42 \mathrm{mg} / \mathrm{m}^{3}
$$

If the Russian standard value for air exchange (90 $\mathrm{m}^{3} / \mathrm{h}$ ) was used, the result would be somewhat lower $\left(8.88 \mathrm{mg} / \mathrm{m}^{3}\right)$.

Anyway, the results obtained are disappointing. Due to the lack of any standard values for residential premises, the result can only be compared with standard values for working premises in the range from $M A C_{m s}$ to $M A C_{w a}$. The concentration estimate obtained with a number of lowering assumptions exceeded even the hard-to-explain value of $\mathrm{MAC}_{\mathrm{ms}}=7 \mathrm{mg} / \mathrm{m}^{3}$ for $\mathrm{NO}$ taken from the Polish standard (see Table 1). The Polish value of $\mathrm{MAC}_{\mathrm{wa}}$ for $\mathrm{NO}_{2}(0.7 \mathrm{mg} /$ $\mathrm{m}^{3}$ ) was exceeded manifold. The Russian standard value of $\mathrm{MAC}_{\mathrm{ms}}$ for $\mathrm{NO}_{\mathrm{x}}\left(5 \mathrm{mg} / \mathrm{m}^{3}\right)$ was also exceeded, but it is the maximum single concentration. A person can stay in the kitchen for much longer time than the exposure time established by that value, i.e. 15 minutes.

According to numerous data, the $\mathrm{NO}_{x}$ concentration of $15 \mathrm{mg} / \mathrm{m}^{3}$ is an extreme value that can be considered relatively safe for people in case of short exposure time. Effects of nitrogen oxides on bronchitis morbidity in children were observed even at concentrations less than $1 \mathrm{mg} / \mathrm{m}^{3}$. These facts substantiated the need for experimental studies.

\section{Experimental studies}

Measurements were carried out in a kitchen with an area of $6.90 \mathrm{~m}^{2}$ in an apartment located on the 6th floor of a standard large-panel 9-story building. The kitchen is equipped with a standard 4-burner Gorenje gas stove with an oven. The burner capacity and flow rate of natural gas with a high content of methane are as follows (given the Wobbe number is within Wo $\left.=45.7 \ldots 54.7 \mathrm{MJ} / \mathrm{m}^{3}\right)$ :

- small burner - $1 \mathrm{~kW}(79.6 \mathrm{l} / \mathrm{h})$;

- two medium burners - $1.9 \mathrm{~kW}(151.3 \mathrm{l} / \mathrm{h})$;

- large burner and oven burner - $3.0 \mathrm{~kW}(238.9 \mathrm{l} / \mathrm{h})$. 
A $14 \times 14 \mathrm{~cm}$ ventilation duct is embedded in a kitchen wall, providing specified natural air extraction. A 172x142 $\mathrm{cm}$ tilt-and-turn window is located in the wall opposite to the gas stove. A refrigerator and a standard kitchen unit are also located in the kitchen.

The composition of the air undergoes dynamic changes during the operation of the gas stove. Therefore, a realtime measurement method was chosen for the studies. The Testo-33 gas analyzer for combustion products (TESTOTERM), meeting the requirements of the Polish standard PN-EN 482: 2002, was used.

Measurements by grid points in increments of $10 \mathrm{~cm}$ in plan view and in increments of $5 \mathrm{~cm}$ in height were carried out; the obtained values were averaged within the range of the standard height of breathing level of an adult standing person (1.50-1.75 m). The measurements were arranged using standard planning methods for experiments.

The experimental results obtained are presented in Table 3 and in Figure 1. According to those results, high concentrations of nitrogen oxides (up to $20 \mathrm{mg} / \mathrm{m}^{3}$ ) form at the height of breathing level in most of the kitchen under normal operating conditions of the gas stove. This value is significantly higher than the maximum single allowable concentration of $\mathrm{NO}_{x}$ specified in standards of various countries (e.g. $5 \mathrm{mg} / \mathrm{m}^{3}$ in Russian standards). At the same time, carbon monoxide in the amount up to $5 \mathrm{mg} / \mathrm{m}^{3}$ is present in the air.

Table 3. Summary data on NOx concentrations in the kitchen air

\begin{tabular}{|c|c|c|c|c|c|c|}
\hline \multirow[t]{2}{*}{ No. } & \multirow[t]{2}{*}{$\begin{array}{l}\text { Experimental condi- } \\
\text { tions }\end{array}$} & \multicolumn{5}{|c|}{$\begin{array}{l}\mathrm{NO}_{x} \text { concentration } \\
\text { (expressed as } \mathrm{NO}_{2} \text { ), } \mathrm{mg} / \mathrm{m}^{3} \text {, } \\
\text { along isolines with the follow- } \\
\text { ing marks }\end{array}$} \\
\hline & & 0 & • & * & $\boldsymbol{\Delta}$ & $\Delta$ \\
\hline 1 & $\begin{array}{l}\text { Four burners are } \\
\text { operating }(7.8 \mathrm{~kW}) \text {, or } \\
\text { the medium and large } \\
\text { burners and oven } \\
\text { burner are operating } \\
(7.9 \mathrm{~kW}) \text {. The door } \\
\text { and the window leaf } \\
\text { are open }\end{array}$ & 20 & 10 & 5 & 3 & 1 \\
\hline 2 & $\begin{array}{l}\text { Two medium burners } \\
\text { are operating ( } 3.8 \\
\mathrm{~kW}) \text {, or the small } \\
\text { burner and oven burn- } \\
\text { er are operating ( } 4.0 \\
\mathrm{~kW}) \text {. The door and the } \\
\text { window leaf are open }\end{array}$ & 13 & 6 & 4 & 2 & $<1$ \\
\hline 3 & $\begin{array}{l}\text { Two medium burners } \\
\text { are operating ( } 3.8 \\
\mathrm{~kW}) \text {, or the small } \\
\text { burner and oven } \\
\text { burner are operating } \\
(4.0 \mathrm{~kW}) \text {. The door } \\
\text { and the window leaf } \\
\text { are closed }\end{array}$ & 18 & 9 & 5 & 4 & 1 \\
\hline
\end{tabular}

\section{Notes:}

1. Measurements under conditions 2 and 3 were carried out by isolines determined under the conditions of the first experiment.

2. The absolute maximum concentration was recorded under conditions 1 , at a height of $1.65 \mathrm{~m}$ from the floor marked in the scheme, and totaled $28 \mathrm{mg} / \mathrm{m}^{3}$.

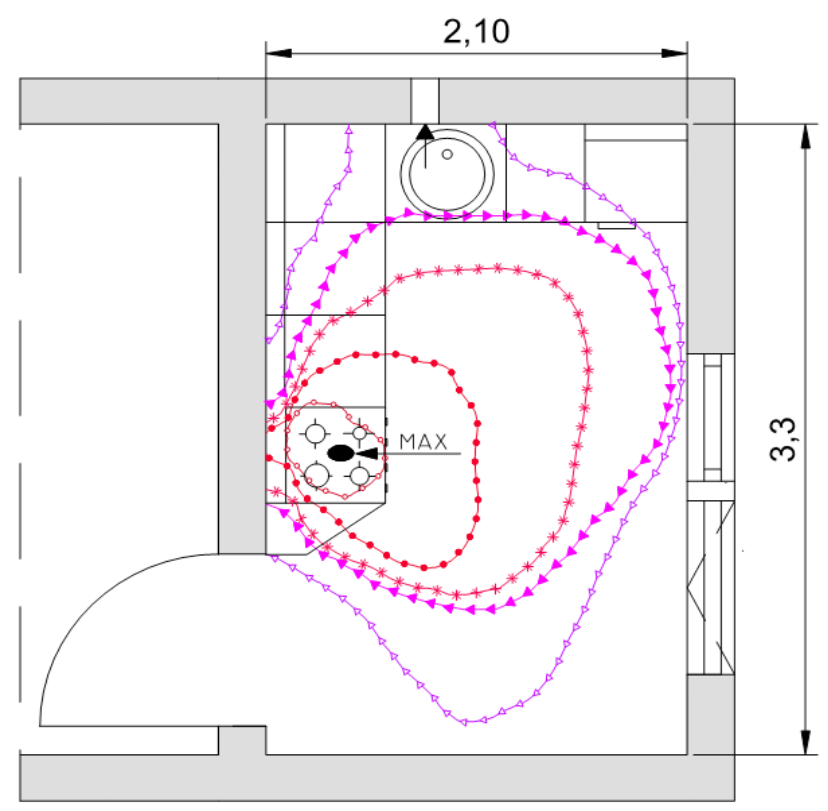

Figure 1. Isolines of nitrogen oxides' concentrations in the kitchen air

\section{Conclusions}

1. Combustion products of household gas stoves are released directly into the air of residential premises, where people spend much time.

In this case, nitrogen oxides inevitably forming upon combustion of organic fuels are main harmful substances. Standard values for the $\mathrm{NO}_{\mathrm{x}}$ concentration in combustion products or in the apartment air are not specified.

2. Theoretical calculations revealed possible formation of NOx high concentrations in the air of a gas-supplied kitchen. The various standard values, analyzed in the study, may be exceeded several-fold and more in the air of the working area and in the outdoor air.

The experimental studies confirmed those calculations. The $\mathrm{NO}_{\mathrm{x}}$ concentration in the air of a standard kitchen exceeds all standard values known to the authors severalfold even in case of short exposure time (up to $15 \mathrm{~min}$ ).

3. Long stay in an environment contaminated with nitrogen oxides poses a threat to health and requires immediate actions of specialists.

On the one hand, it is necessary to introduce regulations for the concentration of harmful substances in the air of residential premises.

Secondly, technical actions shall be taken to improve ventilation of gas-supplied apartments. 


\section{References}

Bieniek, M. (2008). Wpływ tlenków azotu na jakość powietrza w pomieszczeniach [The influence of nitrogen oxides on indoor air quality]. Prace naukowe GIG Górnictwo i Środowisko [Scientific papers of GIG Gornictwo i Srodowisko], 2, pp.2-17. (in Polish)

Central Statistical Office (2017). Zużycie energii w gospodarstwach domowych w 2015 r [Energy consumption in households in 2015]. Available at: https://stat.gov.pl/files/gfx/portalinformacyjny/pl/defaultaktualnosci/5485/2/3/1/zuzycie_energii_w_ gospodarstwach_domowych_w_2015_r..pdf (accessed on: 21.01.2018) (in Polish)

Federal Agency on Technical Regulating and Metrology (2006). GOSTR 50696-2006: Pribory gazovye bytovye dlia prigotovleniia pishchi. Obshchie tekhnicheskie trebovaniia i metody ispytanii [GOST R 50696-2006: household gas cooking appliances. General technical requirements and test methods]. Moscow: Rosstandart. (in Russian)

Logue, J.M., Klepeis, N.E., Lobscheid, A.B., Singer, B.C. (2014). Pollutant Exposures from Natural Gas Cooking Burners: A Simulation-Based Assessment from Southern California. Environ Health Perspectives, 122(1), pp.43-50. DOI: 10.1289/ ehp.1306673

Miller, R. (1997). Badanie emisji zanieczyszczeń z kuchenek gazowych [Examination of pollutant emissions from gas stoves]. Ochrona Środowiska [Environmental Protection], 1(64), pp.33-37. (in Polish)

Minister of the Environment (2012). W sprawie poziomów niektórych substancji w powietrzu [On the levels of certain substances in the air]. (in Polish)

Minister of Health and Social Welfare (1996). W sprawie dopuszczalnych stężeń i natężeń czynników szkodliwych dla zdrowia, wydzielanych przez materiały budowlane, urządzenia i elementy wyposażenia w pomieszczeniach przeznaczonych na pobyt ludzi [The permissible concentrations and intensities of factors harmful to health, emitted by construction materials, devices and elements of equipment in rooms intended for human stay] (in Polish)

Minister of Labor and Social Policy (2014). W sprawie najwyższych dopuszczalnych stężeń i natężeń czynników szkodliwych dla zdrowia $w$ środowisku pracy [On the highest allowable concentrations and intensities of factors harmful to health in the work environment]. Warsaw. (in Polish)

Polska Spółka Gazownictwa (2016). Strategia rozwoju na lata 2016-2022 [Development strategy for 2016-2022]. Available at: https://www.psgaz.pl/documents/21201/329214/Strategia+PSG+2016+-+2022.pdf/a95241fa-85d1-4ee6-8de7-906792e30cb4 (accessed on: 21.01.2018) (in Polish)

Polski komitet normalizacyjny (2000). Polska norma PN-83/B-03430+A3:2000. Wentylacja w budynkach mieszkalnych, zamieszkania zbiorowego i użyteczności publicznej [Polish standard PN-83 / B-03430 + A3: 2000. Ventilation in residential buildings, collective housing and public utilities.] Warszawa. (in Polish)

Santarsiero, A., Musmeci, L., Fuselli, S. (eds) (2015). Workshop. La qualita dell'aria indor: acttuallesituazione national e comuntaria. L'esperienza del Gruppo di Studio Nationale sull' Inquinamento Indoor [The quality of the air indor: acttualle national situation and comuntaria. The experience of the Nationale Study Group on Indoor Pollution]. Instituto Supriore di Sanita Roma, 28 May 2014. Ropporti ISTISAN 15/4. (in Italian)

Skowroński, P. (1997). Użytkowanie i substytucja nośników energii w mieszkalnictwie w kontekście problemu emisji gazów cieplarnianych [The use and substitution of energy carriers in housing in the context of the problem of greenhouse gas emissions]. Biuletyn Instytutu Techniki Cieplnej Politechniki Warszawskiej [Journal of Power of Technologies], 85, pp.21-31. (in Polish)

Szkarowsk,i A. (2014). Spalanie gazów. Teoria, praktyka, ekologia [Burning of gases. Theory, practice, ecology]. Warszawa: Publishing house WNT. (in Polish) 